\title{
Increase in numbers of CD8 positive lymphocytes and eosinophils in peripheral blood of subjects with late asthmatic reactions induced by toluene diisocyanate
}

\author{
Susetta Finotto, Leonardo M Fabbri, Vanda Rado, Cristina E Mapp, Piero Maestrelli
}

\begin{abstract}
Occupational asthma induced by toluene diisocyanate (TDI) shares several features with allergic asthma, but the mechanism of action of TDI is poorly understood. Ten sensitised subjects, previously shown to develop a dual or late asthmatic reaction after inhaling TDI were examined. In each subject, forced expiratory volume in one second $\left(\mathrm{FEV}_{1}\right)$ was measured and venous blood was taken before, and 30 minutes and eight, 24, 48, and 72 hours after exposure to TDI (0.005-0.015 ppm for 1030 minutes). Filtered air was used as a control. Differential leucocyte counts were determined and phenotypic analysis was performed by immunofluorescence on mononuclear cells using monoclonal antibodies (anti-CD3, antiCD4, anti-CD8, and anti-HLA-DR). Five subjects developed a dual asthmatic reaction and five had a late reaction. Percentage of CD8 positive lymphocytes increased significantly eight hours after exposure to TDI (from $27 \pm 3$ (SEM) \% to $42 \cdot 1 \pm 5 \%$ ) in the subjects with an isolated late reaction. A delayed significant further increase in suppressor/cytotoxic $T$ lymphocytes was seen in seven of the 10 subjects 48 hours after active exposure (from $27 \pm 2 \%$ to $42 \pm 4.8 \%$ ), irrespective of the type of asthmatic reaction developed after exposure to TDI. Eosinophil percentage increased from $2 \cdot 5 \% \pm 1.0$ to $6 \cdot 4 \% \pm 1 \cdot 224$ hours after exposure to TDI and the increase was sustained for up to 48 hours $(4 \cdot 7 \pm 1 \cdot 1 \%)$. No significant variations of $F E V_{1}$ or cell percentages were seen in the controls. In conclusion, the events triggered by exposure to TDI in sensitised subjects included
\end{abstract}

Institute of Occupational Medicine, University of Padova, Italy

S Finotto, L M Fabbri, V Rado, C E Mapp, P Maestrelli changes in lung function and systemic effects which lasted longer than bronchoconstriction and concerned suppressor/cytotoxic lymphocytes and eosinophils. These results suggest that TDI induced late asthmatic reactions may be associated with an immunological response to TDI or to its products.

Exposure to isocyanates causes asthma in up to $5 \%$ of people. ${ }^{1}$ The mechanism of isocyanate induced asthma is unknown. Early, late, or dual asthmatic reactions can be induced by inhalation of low concentrations of isocyanates in the laboratory, ${ }^{23}$ and late asthmatic reactions and the associated increase of bronchial hyperreactivity are prevented by corticosteroids. ${ }^{4}$ Bronchoalveolar neutrophilia and eosinophilia occur during late asthmatic reactions induced by toluene diisocyanate (TDI). ${ }^{5}$ Although TDI induced asthma shares some of the characteristic features of allergen induced asthma, an allergic mechanism of TDI induced bronchoconstriction is controversial. ${ }^{6-10}$ Alterations in $T$ cell subsets, either in blood or in bronchoalveolar lavage, after allergen induced asthma have been reported, ${ }^{11-13}$ supporting an immune mediated mechanism of bronchoconstriction. We have compared $\mathrm{T}$ cell subpopulations and circulating leucocytes after experimental inhalation of either TDI or filtered air as a control in asthmatics who were previously identified as dual or late responders.

\section{Subjects and methods}

Ten patients with occupational asthma induced by TDI were studied. All subjects gave their written informed consent to participate. When occupational asthma was diagnosed patients were interviewed and underwent intradermal skin tests with common allergens, lung function measurements, and methacholine and TDI inhalation tests. Table 1 gives the 
Table 1 Clinical details, baseline lung function, and response to TDI in 10 patients

\begin{tabular}{|c|c|c|c|c|c|c|c|}
\hline \multirow[b]{2}{*}{ Patient No } & \multirow[b]{2}{*}{$\operatorname{Sex} \star$} & \multirow[b]{2}{*}{ Age (y) } & \multirow[b]{2}{*}{ Atopy } & \multirow{2}{*}{$\begin{array}{l}\text { Pre TDI FEV } \\
\text { (\% predicted) }\end{array}$} & \multirow{2}{*}{$\begin{array}{l}\text { Pre TDI PD } 20-F E V_{1} \\
\text { (mg methacholine) }\end{array}$} & \multicolumn{2}{|c|}{$\begin{array}{l}\text { Maximum fall in FEV, } \\
\text { after } T D I\end{array}$} \\
\hline & & & & & & Early (\%) & Late (\%) \\
\hline \multicolumn{8}{|c|}{ Dual responders } \\
\hline $\begin{array}{l}1 \\
2 \\
3 \\
4 \\
5\end{array}$ & $\begin{array}{l}\mathbf{M} \\
\mathbf{W} \\
\mathbf{M} \\
\mathbf{M} \\
\mathbf{M}\end{array}$ & $\begin{array}{l}24 \\
19 \\
20 \\
50 \\
40\end{array}$ & $\begin{array}{l}- \\
+ \\
+ \\
+ \\
-\end{array}$ & $\begin{array}{r}90 \\
103 \\
76 \\
106 \\
94\end{array}$ & $\begin{array}{l}0.26 \\
0.43 \\
0.08 \\
0.18 \\
0.07\end{array}$ & $\begin{array}{l}24 \\
25 \\
62 \\
18 \\
37\end{array}$ & $\begin{array}{l}32 \\
24 \\
53 \\
34 \\
43\end{array}$ \\
\hline \multicolumn{8}{|c|}{ Late responders } \\
\hline $\begin{array}{r}6 \\
7 \\
8 \\
9 \\
10\end{array}$ & $\begin{array}{l}W \\
W \\
W \\
W \\
W \\
M\end{array}$ & $\begin{array}{l}20 \\
36 \\
34 \\
45 \\
26\end{array}$ & $\begin{array}{l}- \\
\overline{+} \\
- \\
-\end{array}$ & $\begin{array}{l}103 \\
108 \\
134 \\
106 \\
109\end{array}$ & $\begin{array}{l}0.21 \\
0.06 \\
0.51 \\
0.13 \\
0.12\end{array}$ & $\begin{array}{r}7 \\
0 \\
11 \\
11 \\
8\end{array}$ & $\begin{array}{l}36 \\
53 \\
21 \\
46 \\
60\end{array}$ \\
\hline
\end{tabular}

${ }^{\star} M=$ Man; $W=$ woman.

clinical details. The patients developed a significant bronchoconstriction to less than $0.7 \mathrm{mg}$ of inhaled methacholine, indicating that they had bronchial hyperreactivity. ${ }^{14}$ All subjects were non-smokers and at the beginning of the study they had been free of symptomatic respiratory infections and of exposure to isocyanates for at least four weeks.

\section{DESIGN OF THE STUDY}

The subjects were examined on two occasions. On one occasion they were exposed to TDI, on the other to filtered air (control) in a single blind trial. If the first exposure was TDI, the control exposure was performed at least a month later. The control experiment could not be done in patient No 6 , as she withdrew from the study for personal reasons. Forced expiratory volume in one second $\left(\mathrm{FEV}_{1}\right)$ was measured before exposure and at 30 minutes, hourly for eight hours, and then 24 hours after exposure. Venous blood was taken before each exposure, and 30 minutes and eight, 24, 48, and 72 hours after exposure. Total and differential leucocyte numbers and $T$ cell subpopulations were measured in each blood sample.

\section{INHALATION CHALLENGE WITH METHACHOLINE}

Airway responsiveness to methacholine was assessed as previously described. ${ }^{14}$ Aerosols were generated by a De Vilbiss 646 nebuliser (De Vilbiss Co, Somerset, PA) connected to a Rosenthal French dosimeter (R) (Johns Hopkins University, Baltimore, MA) driven by compressed air. Five inhalations were taken of phosphate buffered saline and of each increasing doubling dose of methacholine $(0.5$ to $64 \mathrm{mg} / \mathrm{ml})$. These were given at five minute intervals until a $20 \%$ fall in $\mathrm{FEV}_{1}$ was measured three minutes after the beginning of each set of inhalations of methacholine aerosol. The cumulative dose of methacholine producing a $20 \%$ fall in $\mathrm{FEV}_{1}\left(\mathrm{PD}_{20} \mathrm{FEV}_{1}\right)$ was calculated.

\section{INHALATION CHALLENGE WITH TDI}

Subjects were exposed to TDI $(0.005-0.015 \mathrm{ppm})$ in a $9.0 \mathrm{~m}^{3}$ exposure chamber as previously described..$^{14}$ The TDI atmosphere was generated by blowing air over the surface of TDI $(20 \mathrm{ml})$ in a $200 \mathrm{ml}$ glass washing bottle. The flow rate of air was controlled by a rotameter calibrated at a flow rate of $2 \mathrm{l} / \mathrm{min}$. A fan in the chamber ensured adequate mixing and circulation. The concentration generated was measured with MDA Model 7005 isocyanate detection equipment (MDA Scientific Inc, Glenview, Ill).

The subject was seated close to the detection equipment. Each subject was watched through the windows of the chamber. The exposure time was 30 minutes, or until the appearance of the symptoms of asthma in the subjects who developed an early asthmatic reaction. The $\mathrm{FEV}_{1}$ was measured using a dry bellows spirometer (Ohio Mod 840, Houston, Tx). On the control day, the same experimental procedure was adopted but subjects were exposed to filtered air.

COUNTING OF BLOOD CELLS AND T LYMPHOCYTE SUBPOPULATIONS

Total numbers of blood erythrocytes and leucocytes were counted with a Coulter counter (Coulter Electronics Ltd, Northwell Drive, Luton, England). Leucocyte differential counts were performed on a glass slide smear treated with Wright-Giemsa stain.

Mononuclear cells were separated from $10 \mathrm{ml}$ of heparinised venous blood by centrifugation on a Ficoll-Paque gradient. Cells at the interface were washed twice with saline and resuspended in Roswell Park Memorial Institute (RPMI) 1640 (Gibco, Grand Island, NJ) at a concentration of $1 \times 10^{6}$ cells/ $\mathrm{ml}$. More than $98 \%$ of mononuclear cells were viable as judged by tripan blue exclusion. Cells were identified using murine monoclonal antibodies antiCD3 (OKT3), anti-CD4 (OKT4) (Ortho Pharmaceuticals, Raritan, NJ), and anti-CD8 (SOT8) (Sorin 
Biomedica, Vercelli, Italy). Irrelevant monoclonal antibody anti-cytokeratin (Dakopatts A/S, Denmark) and diluent of antibodies were used as negative controls. One million cells were incubated with $10 \mu \mathrm{l}$ of monoclonal antibody for 30 minutes at $4^{\circ} \mathrm{C}$. After incubation the cells were washed twice in cold saline and incubated with fluorescein conjugated goat antimouse immunoglobulin (Becton and Dickinson, Sunnyvale, CA) for 30 minutes at $4^{\circ} \mathrm{C}$. Cells were washed twice in cold saline before counting. Two hundred cells were examined blind with a Zeiss fluorescence microscope (Zeiss, Germany) and the results were expressed as a percentage of positively stained cells. Negative controls showed $1 \pm 0 \cdot 3$ (SEM) \% of positive cells. Mononuclear cells expressing the major histocompatibility antigen were identified with a monoclonal antibody anti-HLADR phycoerytrin (PE)-conjugated (Becton and Dickinson, Sunnyvale, CA). For direct immunofluorescence one million cells in RPMI 1640 were incubated with $20 \mu$ lof the antibody for 30 minutes at $4^{\circ} \mathrm{C}$ and then washed three times in cold isotonic saline. Positive cells were counted as above for indirect immunofluorescence.

\section{STATISTICAL ANALYSIS}

The data are presented as the means \pm SEM. Comparisons of values after TDI and after control treatment at the different times were made by one way analysis of variance. Greater than $95 \%$ probability was considered to be significant.

\section{Results}

After exposure to TDI, five subjects developed an isolated late asthmatic reaction, and five subjects had a dual asthmatic reaction (table 1). Patient 4 had a maximum fall in $\mathrm{FEV}_{1}$ of $18 \%$ within the first hour after exposure to TDI. This change in lung function was considered a true early asthmatic reaction as his variability of $\mathrm{FEV}_{1}$ on the control day was $5 \%$ and he showed a definite dual asthmatic reaction on a previous inhalation of TDI. Figure 1 shows the time course of TDI induced bronchoconstriction of patients who exhibited late or dual asthmatic reactions. No bronchoconstriction was elicited by control treatment in any of the subjects.

Numbers of circulating erythrocytes and leucocytes did not change significantly after exposure to TDI. Percentage of eosinophils increased 24 hours after exposure, however, and the increase was sustained for up to 48 hours (table 2). When the results were expressed as absolute cell count, a significant eosinophilia at 24 hours was confirmed. The percentages of neutrophils, lymphocytes, and monocytes did not change (table 2).

The percentage of mature $T$ lymphocytes, as determined by cells stained positively for CD3, ranged from 50 to $90 \%$ and the mean values at baseline and at the different times did not differ significantly in control and active experiments. By contrast the percentage of $\mathrm{CD} 8$ positive cells increased eight hours after exposure to TDI, during the late asthmatic reactions ( $p<0.05$; fig 2 ). The increase was more evident in patients with an isolated late asthmatic reaction (fig 3). A delayed further increase in percentage of CD8 positive cells was detected 48 hours after exposure in seven of the 10 subjects, irrespective of the type of previous asthmatic reaction (fig 3 ). By contrast, $\mathrm{CD} 4$ positive

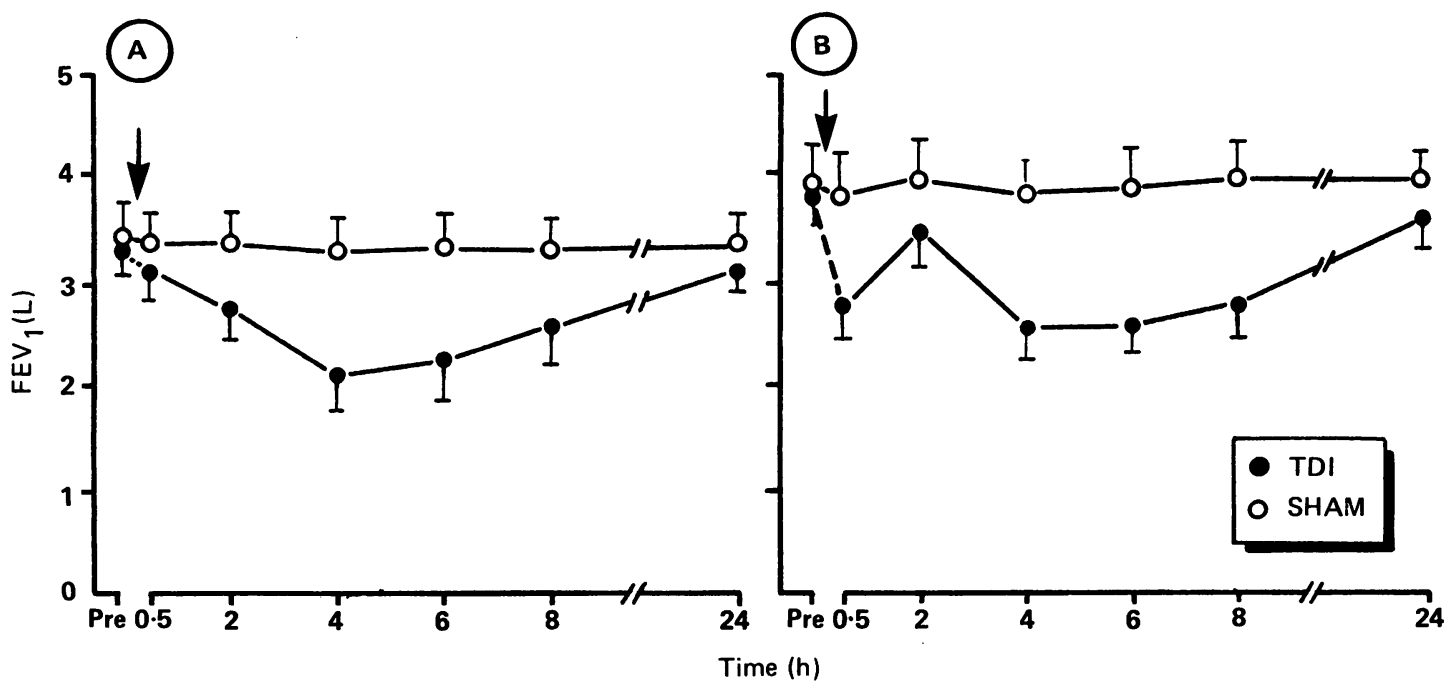

Figure 1 Variations of FEV (mean $\pm S E M)$ after bronchial exposure to $T D I(\bigcirc)$ and filtered air (O) in subjects who developed $(A)$ late asthmatic reactions $(n=5)$ or $(B)$ dual asthmatic reactions $(n=5)$. 
cells did not change and thus the $\mathrm{CD} 4 / \mathrm{CD} 8$ ratio slightly decreased eight and 48 hours after active exposure $(1.53 \pm 0.59$ and $1.62 \pm 0.98)$ compared with baseline $(1 \cdot 8 \pm 0 \cdot 6)$. Also, HLA-DR positive cells slightly increased during TDI induced bronchoconstriction, but the increase was not statistically significant (fig 2).

\section{Discussion}

This paper shows that late asthmatic reactions induced by TDI are associated with an increase in numbers of suppressor/cytotoxic lymphocytes and eosinophils in peripheral blood.

Diurnal variations are unlikely to have influenced our findings as blood was sampled at the same time of

Table 2 Total and differential counts of blood leucocytes in sensitised patients pre and post-exposure to TDI ( $n=10)$ or filtered air $(n=9)$

\begin{tabular}{|c|c|c|c|c|c|c|c|}
\hline \multirow[b]{2}{*}{ Cells } & \multirow[b]{2}{*}{ Treatment } & \multirow[b]{2}{*}{ Pre-exposure } & \multicolumn{5}{|c|}{ Post-exposure } \\
\hline & & & $30 \min$ & $8 h$ & $24 h$ & $48 h$ & $72 h$ \\
\hline Leucocytes $/ \mathrm{mm}^{3} \times 10^{3}$ & $\begin{array}{l}\text { TDI } \\
\text { Control }\end{array}$ & $\begin{array}{c}6 \cdot 4 \\
(0 \cdot 8) \\
5 \cdot 2 \\
(0 \cdot 3)\end{array}$ & $\begin{array}{c}6 \cdot 3 \\
(0 \cdot 7) \\
5 \cdot 3 \\
(0.3)\end{array}$ & $\begin{array}{c}7 \cdot 3 \\
(0.5) \\
6 \cdot 4 \\
(0.6)\end{array}$ & $\begin{array}{c}6.4 \\
(0.6) \\
5.0 \\
(0.2)\end{array}$ & $\begin{array}{c}6 \cdot 7 \\
(0.7) \\
6 \cdot 1 \\
(1.0)\end{array}$ & $\begin{array}{c}6.1 \\
(0.5) \\
4.9 \\
(0.2)\end{array}$ \\
\hline Neutrophils (\%) & $\begin{array}{l}\text { TDI } \\
\text { Control }\end{array}$ & $\begin{array}{l}60 \cdot 8 \\
(4 \cdot 8) \\
60 \cdot 8 \\
(2 \cdot 3)\end{array}$ & $\begin{array}{l}60 \cdot 8 \\
(3 \cdot 2) \\
61 \cdot 7 \\
(2 \cdot 8)\end{array}$ & $\begin{array}{l}66 \cdot 3 \\
(3 \cdot 7) \\
64 \cdot 2 \\
(1 \cdot 6)\end{array}$ & $\begin{array}{c}62 \cdot 2 \\
(2 \cdot 9) \\
61 \cdot 0 \\
(2 \cdot 7)\end{array}$ & $\begin{array}{l}59 \cdot 2 \\
(2 \cdot 9) \\
60 \cdot 0 \\
(2 \cdot 5)\end{array}$ & $\begin{array}{l}63.6 \\
(4.1) \\
60.4 \\
(3.9)\end{array}$ \\
\hline Lymphocytes (\%) & $\begin{array}{l}\text { TDI } \\
\text { Control }\end{array}$ & $\begin{array}{c}34 \cdot 0 \\
(4 \cdot 0) \\
34 \cdot 2 \\
(2 \cdot 0)\end{array}$ & $\begin{array}{l}36 \cdot 7 \\
(3 \cdot 9) \\
33 \cdot 8 \\
(2 \cdot 3)\end{array}$ & $\begin{array}{l}30 \cdot 5 \\
(3 \cdot 5) \\
33 \cdot 2 \\
(1 \cdot 3)\end{array}$ & $\begin{array}{l}28 \cdot 6 \\
(2 \cdot 2) \\
34 \cdot 0 \\
(2 \cdot 0)\end{array}$ & $\begin{array}{l}31.0 \\
(2 \cdot 2) \\
35 \cdot 8 \\
(2 \cdot 6)\end{array}$ & $\begin{array}{l}29 \cdot 4 \\
(2 \cdot 1) \\
34 \cdot 7 \\
(3 \cdot 2)\end{array}$ \\
\hline Eosinophils (\%) & $\begin{array}{l}\text { TDI } \\
\text { Control }\end{array}$ & $\begin{array}{c}2.5 \\
(0.7) \\
2 \cdot 7 \\
(0.8)\end{array}$ & $\begin{array}{c}2 \cdot 7 \\
(0 \cdot 7) \\
2 \cdot 1 \\
(0 \cdot 5)\end{array}$ & $\begin{array}{c}1.2 \\
(0.4) \\
0.8 \\
(0.1)\end{array}$ & $\begin{array}{r}6 \cdot 4^{\prime} \\
(1 \cdot 2) \\
2 \cdot 6^{6} \\
(0 \cdot 8)\end{array}$ & $\begin{array}{c}4 \cdot 7^{\mathrm{c}} \\
(1 \cdot 1) \\
2 \cdot 0^{\mathrm{d}} \\
(0 \cdot 6)\end{array}$ & $\begin{array}{c}3.9 \\
(1 \cdot 1) \\
2 \cdot 1 \\
(0.6)\end{array}$ \\
\hline Monocytes (\%) & $\begin{array}{l}\text { TDI } \\
\text { Control }\end{array}$ & $\begin{array}{c}2 \cdot 7 \\
(1 \cdot 0) \\
2 \cdot 1 \\
(1 \cdot 0)\end{array}$ & $\begin{array}{c}2 \cdot 0 \\
(1 \cdot 2) \\
2 \cdot 3 \\
(0 \cdot 9)\end{array}$ & $\begin{array}{c}2.2 \\
(0.9) \\
1 \cdot 7 \\
(0.6)\end{array}$ & $\begin{array}{c}3.4 \\
(1.9) \\
2.6 \\
(0.8)\end{array}$ & $\begin{array}{c}5 \cdot 4 \\
(2 \cdot 8) \\
2 \cdot 0 \\
(1 \cdot 3)\end{array}$ & $\begin{array}{c}3 \cdot 7 \\
(2 \cdot 2) \\
2 \cdot 7 \\
(1 \cdot 3)\end{array}$ \\
\hline
\end{tabular}

Results are expressed as means (SEM). Analysis of variance (one way); $a v$ and $c v d, p<0.05$.
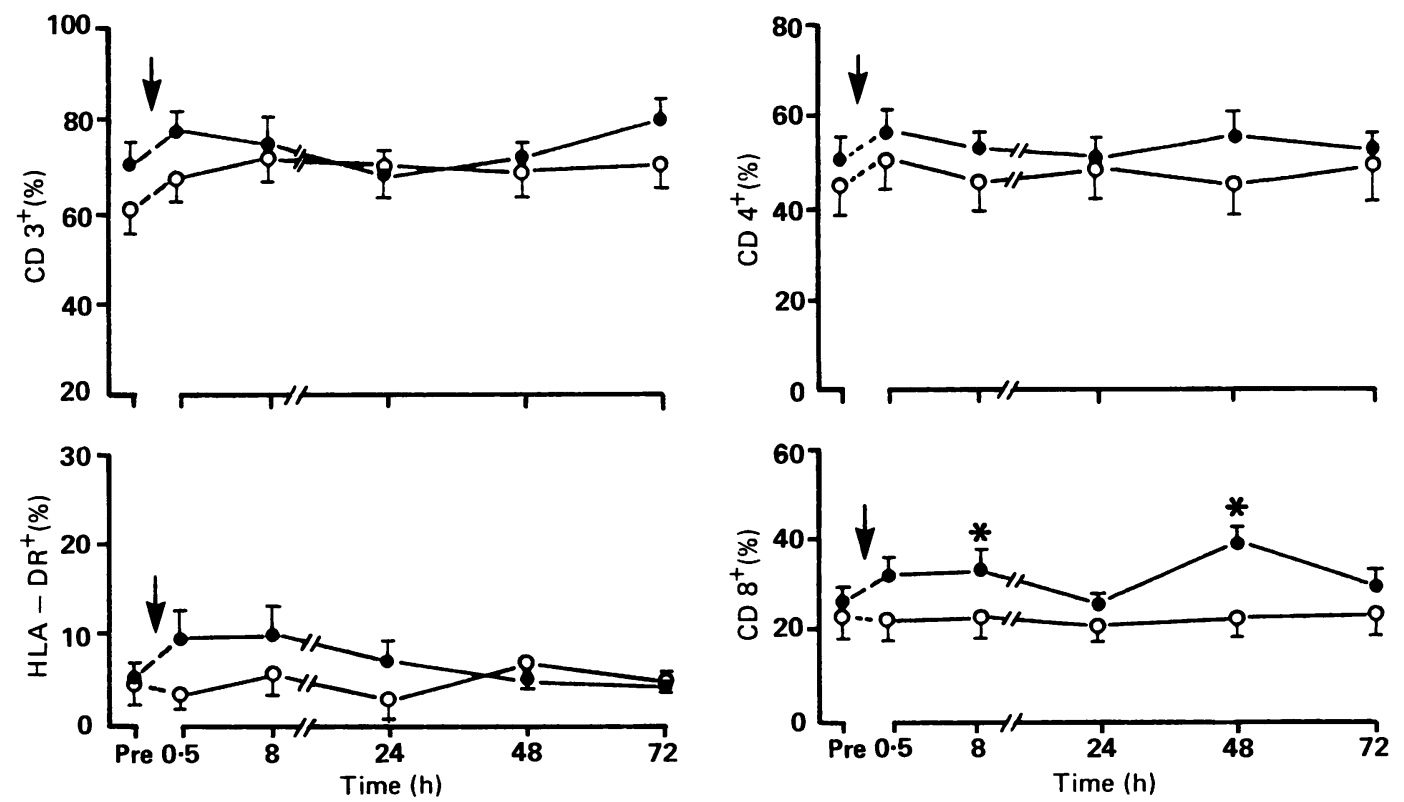

Figure 2 Percentages of blood mononuclear cells stained with monoclonal antibodies anti-CD3, anti-CD4, anti-CD8, and anti-HLA-DR pre and post challenge with TDI ( ) and filtered air ( $O$ ) in 10 subjects who exhibited late or dual asthmatic reactions after active exposure. Arrows indicate the bronchial challenges. ${ }^{\star} p<0.05$; analysis of variance (one-way). 

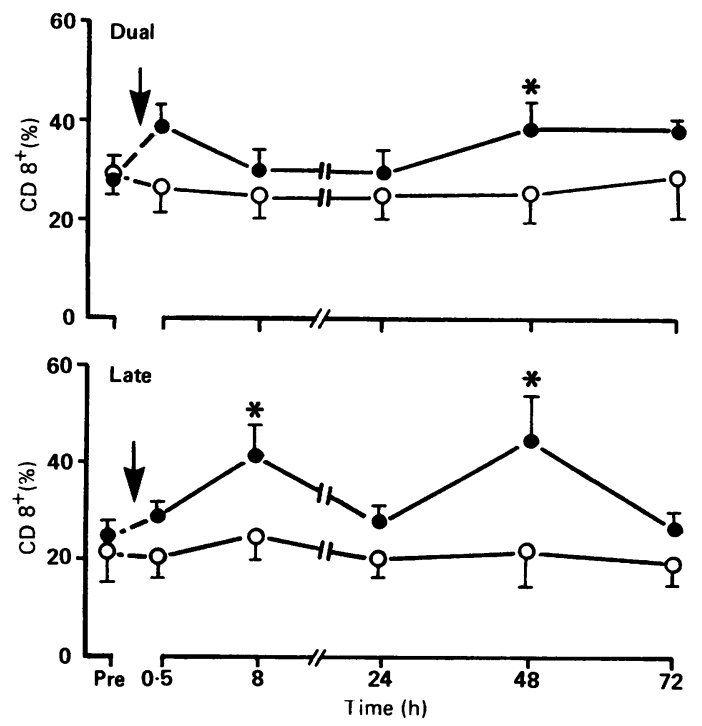

Figure 3 Different pattern of variations of the CD8 positive lymphocytes in TDI induced dual (upper panel) and late (lower panel) asthmatic reactions.

- TDI; $\bigcirc$ control. ${ }^{\star} p<0.05$; analysis of variance (one-way).

day both after TDI and control exposure except for the eight hour time point. Because no variations of total leucocyte numbers and percentages of CD3 positive cells were seen at the different times, it was considered appropriate to express the results as original percentages.

Lung functions returned to baseline values within 24 hours after exposure to TDI and no patients had any respiratory symptom later. No drugs, except inhaled salbutamol, were allowed and blood was sampled at least six hours after salbutamol. Therefore, the changes we detected 24 to 72 hours after TDI are unlikely to be due to a drug effect, recurrent asthma, or inadvertent re-exposure to isocyanates, as the patients were kept in hospital during the study.

Subjects with late and dual asthmatic reactions exhibited different kinetics of increase in CD8 positive cells at eight hours after exposure to TDI indicating a possible relation between $T$ lymphocytes and pattern of bronchoconstriction. Recirculation of CD8 positive cells from the lungs where they had accumulated, ${ }^{13}$ or selective recruitment of helper lymphocytes into the lung might explain our findings. ${ }^{15}$

Different mechanisms are probably associated with the subsequent increase in eosinophils and CD8 positive lymphocytes shown by most subjects 24 to 48 hours after exposure to TDI when the TDI induced bronchoconstriction had disappeared. Late asthmatic reactions induced by isocyanates are associated with airway inflammation, ${ }^{16}$ which lasts longer than bronchoconstriction. ${ }^{14}$ The changes seen in peripheral blood 24 to 48 hours after active exposure may well be the result of an ongoing inflammatory process in the lung. Several reports ${ }^{17}{ }_{18}$ showed raised blood eosinophil numbers after allergen induced late asthmatic reaction, with a time course similar to our findings. ${ }^{18}$ These results are in agreement with our own previous observations that late but not early reactions induced by TDI are associated with neutrophilia and a slight eosinophilia in bronchoalveolar lavage at eight hours after exposure. ${ }^{5}$ Late response in the lung induced by allergen inhalation is associated with activation of circulating leucocytes. ${ }^{19}$ Alterations in CD4 positive subsets of lymphocytes but not in CD8 positive ones have been reported after allergen induced asthma, whereas bronchoconstriction induced by a nonspecific stimulus such as methacholine had no effect. ${ }^{113}$ Whether the observed increase of CD8 positive cells is a feature of isocyanate induced asthma or the result of different experimental conditions is difficult to establish.

The CD8 positive lymphocytes may be functionally distinguished in suppressor and cytotoxic cells. In mice, suppressor cells can be induced by injection of antigen. ${ }^{20}$ In man, antigen specific suppressor cells are detectable in blood after repeated administration of allergen to allergic subjects. ${ }^{21}$ These cells have been identified as CD8 positive lymphocytes. ${ }^{22}$ Suppressor cells bearing a CD8 marker are induced in vitro by non-antigenic stimuli such as leukotriene B4 (LTB4) ${ }^{23}$ We previously found an increase of LTB4 in bronchoalveolar lavage fluid during late asthmatic reaction induced by $\mathrm{TDI},{ }^{24}$ and LTB4 may play a part in the increase of CD8 positive cells in our patients.

These data indicate that the events triggered by exposure to TDI in sensitised subjects include functional changes in the lung and systemic effects that last longer than bronchoconstriction and concern blood lymphocytes and eosinophils. Although further studies on cell population in the airways and on function of CD8 positive lymphocytes are needed, it is conceivable that an immune mechanism plays a part in isocyanate induced asthma.

We thank L Zedda and C Marendon for technical assistance and $G$ Fulgeri and $\mathrm{L}$ Tolin for secretarial help. The work was supported by the Italian National Research Council grant No 88.02119.04, and by the Italian Ministry of Education.

Requests for reprints to: Dr P Maestrelli, Institute of Occupational Medicine, University of Padova, via J Facciolati, 71, 35127 Padova, Italy. 1 National Institute for Occupational Safety and Health Center for
Disease Control. A recommended standard for occupational
exposure to diisocyanates. Cincinnati: NIOSH, 1979. (DHEW 
(NiOSH) publ No 78-125, reprinted.)

2 Mapp CE, Boschetto P, Dal Vecchio L, Maestrelli P, Fabbri LM. Occupational asthma due to isocyanates. Eur Respir $J$ 1988;1:273-9.

3 O'Brien M, Newman-Taylor AJ, Burge PJ, et al. Toluene diisocyanate-induced asthma. II. Inhalation challenge tests and bronchial reactivity studies. Clin Allergy 1979;9:7-15.

4 Fabbri LM, Chiesura Corona P, Dal Vecchio L, et al. Prednisone inhibits late asthmatic reactions and the associated increase in airway responsiveness induced by toluene diisocyanate in sensitized subjects. Am Rev Respir Dis 1985;132 $1010-4$.

5 Fabbri LM, Boschetto P, Zocca E, et al. Bronchoalveolar neutrophilia during late asthmatic reactions induced by toluene diisocyanate. Am Rev Respir Dis 1987;136:36-42.

6 Bernstein IL. Isocyanate-induced pulmonary diseases: a current perspective. J Allergy Clin Immunol 1982;70:24-31.

7 Butcher BT, O'Neil CE, Reed MS, Salvaggio JE. Radioallergosorbent testing of toluene diisocyanate-reactive individuals using p-tolyl isocyanate antigen. J Allergy Clin Immunol 1980;66:213-6.

8 Paggiaro PL, Filieri M, Loi AM, et al. Absence of IgG antibodies to TDI-HSA in a radioimmunological study. Clin Allergy 1983;13:75-9.

9 Patterson R, Hargreave FE, Grammer LC, Harris KE, Dolovich $\mathrm{J}$. Toluene diisocyanate respiratory reactions. Int Arch Allergy Appl Immunol 1987;84:93-100.

10 Cartier A, Grammer L, Malo J-L, et al. Specific serum antibodies against isocyanates; association with occupational asthma. J Allergy Clin Immunol 1989;84:507-14.

11 Gerblich AA, Campbell AE, Shuyler MR. Changes in Tlymphocyte subpopulations after bronchial provocation in asthmatics. N Engl J Med 1984;310:1349-52.

12 Richerson HB, Metzger WJ, Hunningake GW. Experimental models of bronchial asthma in man and in rabbit. In: Kay AB ed. Asthma: clinical pharmacology and therapeutic progress. Oxford: Blackwell Scientific Publications, 1986:23-32.

13 Gonzalez MC, Diaz P, Galleguillos FR, Ancic P, Cromwell O, Kay AB. Allergen-induced recruitment of bronchoalveolar helper (OKT4) and suppressor (OKT8) T-cells in asthma.
Am Rev Respir Dis 1987;136:600-4.

14 Mapp CE, Polato R, Maestrelli P, Hendrick DJ, Fabbri LM. Time course of the increase in airway responsiveness associated with late asthmatic reactions to toluene diisocyanate in sensitized subjects. J Allergy Clin Immunol 1985;75:568-75.

15 Metzger WJ, Zavala D, Richerson HB, et al. Local allergen challenge and bronchoalveolar lavage of allergic asthmatic lungs. Am Rev Respir Dis 1987;135:433-40.

16 Boschetto P, Fabbri LM, Zocca E, et al. Prednisone inhibits late asthmatic reactions and airway inflammation induced by toluene diisocyanate in sensitized subjects. J Allergy Clin Immunol 1985;80:261-7.

17 Booij-Noord H, De Vries K, Sluiter HJ, Orie NGM. Late bronchial obstructive reaction to experimental inhalation of house dust extract. Clin Allergy 1972;2:43-61.

18 Durham SR, Kay AB. Eosinophils, bronchial hyperreactivity and late-phase asthmatic reactions. Clin Allergy 1985;15: 411-8.

19 Durham SR, Caroll M, Walsh GM, Kay AB. Leucocyte activation in alkergen-induced late-phase asthmatic reactions. N Engl J Med 1984;311:1398-402.

20 Takatsu K, Ishizaka K. Reaginic antibody formation in the mouse. VII. Induction of suppressor T cells for IgE and IgG antibody responses. J Immunol 1976;116:1257-64.

21 Rocklin RE, Sheffer AL, Greinder DK, Melmon KL. Generation of antigen-specific suppressor cells during allergy desensitization. N Engl J Med 1980;302:1213-8.

22 Hiroshi Nagaya MD. Induction of antigen-specific suppressor cells in patients with hay fever receiving immunotherapy. $J$ Allergy Clin Immunol 1986;75:388-94.

23 Atiuru D, Goodwin JS. Control of polyclonal immunoglobulin production from human lymphocytes by leukotrienes; leukotriene B4 induces an OKT $8(+)$, radiosensitive suppressor cell from resting, human OKT $8(-)$ T cells. $J$ Clin Invest 1984; 74:1440-50.

24 Zocca E, Fabbri LM, Boschetto P, et al. Leukotriene B4 and late asthmatic reactions induced by toluene diisocyanate. $J$ Appl Physiol 1990;68:1576-80.

Accepted 2 July 1990 